\title{
Antagonisme Bacillus terhadap Infeksi Layu Fusarium pada Bibit Pisang Hasil Kultur Jaringan
}

\section{Bacillus Antagonism toward Fusarium Wilt on Banana Seedling Originated from Tissue Culture}

\author{
Hadiwiyono $^{2)}$, Arief Widyantoro ${ }^{1)}$, Salim Widono ${ }^{1)}$
}

\begin{abstract}
Fusarium wilt (Fusarium oxysporum f.sp. cubense) is an important disease in banana. Fusarium wilt was hard to control because the pathogen can survive in many kind of soils type although there is no host. Therefore, overcoming the disease is urgently needed such as biological control. The endophytic Bacillus of banana was begun to use as antagonist agent to the pathogen. This research aimed to study the mechanism of antagonism and physiological character of Bacillus. There were 27 Bacillus isolates examined in-vitro to test the production of IAA, HCN, chitinase, pectinase, and antagonism. The top ten isolates based on the test in vitro were used to test in planta. The research showed that Bacillus were able to produce IAA, HCN, chitinase, pectinase, and able to retard the growth of Foc colony. The application of isolat B25 on banana seedling could decrease the disease intensity but still unable to prevent the fusarium wilt infection.
\end{abstract}

Keywords: banana, fusarium wilt, in vitro antagonism, Bacillus

\section{PENDAHULUAN}

Pengembangan komoditas pisang di Indonesia masih terhambat adanya penyakit layu fusarium yang disebabkan oleh Fusarium oxysporum f.sp. cubense (Foc). Volume ekspor pisang mencapai angka 5,17 juta ton kemudian menurun sampai 0,14 juta ton di tahun 2006. Produksi pisang nasional tahun 2009 sebesar 6,30 juta lalu mengalami penurunan di tahun 2010 sebesar 5,80 juta ton dan tahun 2011 sebesar 0,80 juta ton (BPS 2012). Pengendalian penyakit layu fusarium direkomendasikan seperti penggunaan fungisida dan kultur teknis, namun belum mampu menekan kejadian penyakit di lapangan (Nasir et al. 2005). Pengendalian hayati diarahkan seiring perkembangan penelitian mengenai agens antagonis. Bacillus merupakan salah satu genus bakteri yang dilaporkan mampu meningkatkan resistensi tanaman (Rebib et al. 2012). Bacillus mampu memproduksi senyawa antifungal yang menyebabkan pembengkakan hifa Foc secara in vitro (Adeline et al. 2008, Arrebola et al. 2010). Karakter morfologi dan fisiologis serta mekanisme penghambatan Bacillus perlu dipelajari untuk mengetahui pengaruhnya terhadap infeksi layu fusarium pisang.

\footnotetext{
1) Undergraduate Student of Study Program of Agrotechnology, Agricultural Faculty of Universitas Sebelas Maret (UNS) in Surakarta.

${ }^{2)}$ Lecturer of Study Program of Agrotechnology, Agricultural Faculty of Universitas Sebelas Maret (UNS) in Surakarta.

Contact Author: hadi_hpt@yahoo.com
}

\section{METODE PENELITIAN}

\section{Karaterisasi Morfologi Koloni Bacillus}

Pengujian secara in vitro dilaksanakan di Laboratorium Hama dan Penyakit Tumbuhan dan Laboratorium Biologi Tanah UNS serta untuk pengujian in planta dilakukan di rumah kasa UNS bulan Januari sampai Desember 2013. Karakterisasi morfologi koloni Bacillus dilaksanakan pada di Laboratorium Hama dan Penyakit Tumbuhan dengan bahan isolat Bacillus endofit pisang. Morfologi koloni Bacillus diamati menurut bentuk, tepi, elevasi, permukaan, dan warna dalam media biakan agar nutrien (NA).

\section{Karakterisasi Fisiologi Bacillus}

Karakterisasi fisiologi Bacillus meliputi uji produksi indole acetic acid (IAA), hidrogen sianida ( $\mathrm{HCN})$, aktivitas kitinase, dan aktivitas pektinase dengan bahan berupa isolat Bacillus, sejumlah media biakan dan IAA sintetis. Produksi IAA Bacillus diukur menurut metode Bresson dan Borges (2003) dengan indikator nilai absorbansi. Produksi HCN secara kualitatif diukur menurut Reddy et al. (2008) dengan indikator warna. Aktivitas kitinase dan pektinase diukur berdasarkan koloni Bacillus pada 4 hari inkubasi pada perlakuan media biakan NA.

\section{Uji Antagonisme In Vitro}

Uji antagonisme in vitro menggunakan rancangan acak lengkap (RAL) dengan metode kultur ganda Bacillus terhadap Foc. Persentase hambatan diukur: Persentase hambatan $=\frac{r 1-r 2}{r 2} \times 100 \%$

dengan $\mathrm{r} 1=$ jari-jari Focmenjauhi Bacillus, $\mathrm{r} 2=$ jari-jari Foc mendekati Bacillus. Analisis data dengan uji $F$ taraf 5\% dan uji Duncan taraf 5\%. 


\section{Uji Filtrat In Vitro}

Uji filtrat Bacillus terhadap Foc in vitro disusun menggunakan RAL dengan metode kultur ganda pada sejumlah Bacillus yang telah dinonaktifkan melalui perlakuan tekanan tinggi. Pengamatan persentase hambatan dan analisis data sama pada uji antagonisme in vitro.

\section{Uji Volatil In Vitro}

Uji volatil (uap biakan) dilakukan menggunakan RAL dengan bahan 27 isolat Bacillus dan Foc sebagai perlakuan serta dua kontrol berupa air steril dan pembawa Bacillus. Masing-masing isolat ditangkupkan satu sama lain pada media biakan yang berbeda, NA untuk Bacillus dan PDA untuk Foc. Pertumbuhan diameter koloni Foc diamati setiap 2 hari sekali selama 8 hari.

\section{Uji Antagonisme In Planta}

Uji antagonisme in planta dilakukan di rumah kasa pada bibit pisang Ambon Kuning secara RAL menggunakan 10 isolat terbaik uji in vitro. Inokulasi Bacillus dilakukan dengan pengocoran sebanyak 25 $\mathrm{ml}$ dengan metode pelukaan pada akar. Intensitas penyakit (IP) dihitung :

$$
I P=\frac{\sum(n \times v)}{N \times Z} \times 100 \%
$$

dengan; $n=$ Jumlah tanaman menunjukan skor tertentu; $v=$ Skor tanaman (skor=layu daun); $N=$ skor tertinggi; $Z$ = seluruh tanaman.

LBKPP dihitung :

$$
\text { LEKPP }=\sum_{i=1}^{n} \frac{X i+1+X 1}{2} X\left(t_{i+1-t i)}\right.
$$

Tabel 1. Karakter koloni isolat Bacillus dengan $\angle B K P P=$ Luas bawah kurva perkembangan penyakit; $X i=$ Intensitas penyakit saat pengamatan minggu ke-l; $t i=$ Waktu pengamatan ke-l; $n=$ Pengamatan pada saat terminal penyakit. Laju infeksi dihitung dengan rumus:

$r=\frac{2 . a}{t}\left(\log \frac{1}{1-X t}-\log \frac{1}{1-X 0}\right)$

dengan $r=$ laju infeksi (per unit per minggu); $t=$ interval pengamatan (mingguan); $X O=$ proporsi penyakit awal pengamatan; dan $X t=$ proporsi penyakit pengamatan ke $t$.

\section{HASIL DAN PEMBAHASAN}

\section{Morfologi Koloni Bacillus}

Karakter morfologi koloni Bacillus asal beberapa tempat di wilayah Surakarta menunjukkan sifat yang bervariasi (Tabel 1). Hal ini terlihat pada bentuk, tepi, elevasi, permukaan, dan warna koloni berbeda-beda. Menurut Hatmanti (2002) bentuk koloni Bacillus dan responsnya terhadap faktor lingkungan cenderung berbeda-beda pada media biakan.

\section{Karakter Fisiologi Bacillus}

Uji produksi IAA 27 isolat Bacillus dengan inkubasi 24 jam menghasilkan konsentrasi berbeda (Tabel 2). Isolat B1, B3, B6, B9 memproduksi IAA tinggi berkisar 9,000 ppm, namun pada B12 dan B30 memproduksi IAA rendah dengan nilai $4,920 \mathrm{ppm}$ dan $4,822 \mathrm{ppm}$. Perbedaan ini dipengaruhi oleh lokasi sampel dan kemampuan Bacillus dalam mengkonversi triptofan

\begin{tabular}{|c|c|c|c|c|c|c|}
\hline \multirow[t]{2}{*}{ Isolat } & \multirow[t]{2}{*}{ Asal } & \multicolumn{5}{|c|}{ Karakter Koloni } \\
\hline & & Bentuk & Tepi & Elevasi & Permukaan & Warna \\
\hline $\mathrm{B} 1$ & Mojolaban & Circular & Entire & Raised & Smooth, Glistening & Putih \\
\hline $\mathrm{B} 2$ & Mojolaban & Irregular & Undulate & Umbonate & Wrinkle & Krem \\
\hline B3 & Mojolaban & Irregular & Undulate & Umbonate & Smooth, Glistening & Putih \\
\hline B4 & Jaten & Rhizoid & Lobate & Umbonate & Smooth, Glistening & Putih \\
\hline B5 & Jaten & Irregular & Undulate & Raised & Smooth, Glistening & Putih \\
\hline $\mathrm{B} 6$ & Jaten & Filamentous & Filamentous & Umbonate & Smooth, Glistening & Putih \\
\hline B7 & Jaten & Rhizoid & Lobate & Umbonate & Smooth, Glistening & Putih \\
\hline B8 & Jaten & Rhizoid & Lobate & Umbonate & Wrinkle & Krem \\
\hline B9 & Karanganyar & Irregular & Undulate & Umbonate & Smooth, Glistening & Putih \\
\hline B10 & Karanganyar & Irregular & Undulate & Umbonate & Smooth, Glistening & Putih \\
\hline B11 & Karanganyar & Irregular & Undulate & Umbonate & Smooth, Glistening & Putih \\
\hline B12 & Karanganyar & Irregular & Undulate & Umbonate & Smooth, Glistening & Putih \\
\hline B13 & Jebres & Irregular & Undulate & Umbonate & Smooth, Glistening & Putih \\
\hline B14 & Tasikmadu & Circular & Entire & Raised & Smooth, Glistening & Putih \\
\hline B15 & Karanganyar & Filamentous & Filamentous & Umbonate & Smooth, Glistening & Putih \\
\hline B16 & Karanganyar & Rhizoid & Lobate & Umbonate & Smooth, Glistening & Putih \\
\hline $\mathrm{B} 17$ & Karanganyar & Circular & Entire & Raised & Smooth, Glistening & Putih \\
\hline B18 & Karanganyar & Filamentous & Filamentous & Umbonate & Smooth, Glistening & Putih \\
\hline B20 & Mojolaban & Rhizoid & Lobate & Umbonate & Wrinkle & Krem \\
\hline B21 & Jebres & Irregular & Undulate & Raised & Smooth, Glistening & Putih \\
\hline B22 & Jebres & Circular & Entire & Raised & Smooth, Glistening & Putih \\
\hline $\mathrm{B} 23$ & Jebres & Irregular & Undulate & Raised & Smooth, Glistening & Putih \\
\hline B24 & Tasikmadu & Irregular & Undulate & Raised & Smooth, Glistening & Putih \\
\hline B25 & Tasikmadu & Irregular & Undulate & Raised & Smooth, Glistening & Putih \\
\hline B26 & Karanganyar & Irregular & Undulate & Raised & Smooth, Glistening & Putih \\
\hline B28 & Karanganyar & Irregular & Undulate & Umbonate & Smooth, Glistening & Putih \\
\hline B30 & Ngargoyoso & Irregular & Undulate & Umbonate & Smooth, Glistening & Putih \\
\hline
\end{tabular}
yang terkandung dalam media King's B menjadi IAA. 
Tabel 2. Karakter fisiologi isolat Bacillus

\begin{tabular}{|c|c|c|c|c|}
\hline \multirow[t]{2}{*}{ Isolat } & \multicolumn{4}{|c|}{ Karakter Fisiologi } \\
\hline & IAA (ppm) & $\mathrm{HCN}$ & Aktivitas Kitinase & Aktivitas Pektinase \\
\hline B1 & 9.661 & - & + & + \\
\hline B2 & 6.851 & - & + & + \\
\hline B3 & 9.580 & - & + & + \\
\hline B4 & 6.149 & - & + & + \\
\hline B5 & 6.851 & - & + & + \\
\hline B6 & 9.132 & - & + & + \\
\hline B7 & 5.172 & - & + & + \\
\hline B8 & 5.839 & - & + & + \\
\hline B9 & 9.615 & - & + & + \\
\hline B10 & 6.402 & - & + & + \\
\hline B11 & 7.247 & - & + & + \\
\hline B12 & 4.920 & - & + & + \\
\hline B13 & 6.121 & - & + & + \\
\hline B14 & 7.408 & - & + & + \\
\hline B15 & 6.592 & - & + & + \\
\hline B16 & 5.086 & - & + & + \\
\hline B17 & 6.759 & - & + & + \\
\hline B18 & 5.592 & - & + & + \\
\hline B20 & 8.586 & - & + & + \\
\hline B21 & 6.868 & - & + & + \\
\hline B22 & 6.075 & - & + & + \\
\hline B23 & 5.856 & - & + & + \\
\hline B24 & 5.184 & - & + & + \\
\hline B25 & 6.747 & - & + & + \\
\hline B26 & 7.678 & - & + & + \\
\hline B28 & 5.845 & - & + & + \\
\hline B30 & 4.822 & - & + & + \\
\hline
\end{tabular}

Keterangan: Produksi HCN: warna kertas saring +++merah bata, ++coklat tua, + coklat muda, -kuning (tidak memproduksi $\mathrm{HCN}$ ).

Aktivitas kitinase dan pektinase: + positif (mendegradasi kitin/pektin), - negatif (tidak mendegradasi kitin/pektin).

Menurut Lee et al. (2004) triptofan adalah prekursor yang berfungsi untuk biosintesis auksin baik mikrob maupun tanaman. Leveau dan Lindow (2004) menambahkan bahwa tanaman dapat mensintesis hormon auksin dari mikrob untuk meningkatkan pertumbuhannya.

Hasil menunjukkan semua isolat Bacillus tidak menghasilkan senyawa sianida. Kertas saring yang berwarna kuning menunjukkan isolat uji tidak memproduksi HCN. Menurut Sutariati et al. (2006) pada uji produksi $\mathrm{HCN}$ berbagai isolat Bacillus, Pseudomonas, dan Serratia, menunjukkan bahwahanya isolat Pseudomonas yang dapat menghasilkan sianida.

Semua isolat Bacillus menghasilkan kitinase dan pektinase ditandai terbentuknya koloni pada agar kitin maupun pektin. Degradasi kitin di alam dapat dilakukan oleh beberapa jenis bakteri, jamur antagonis, aktinomisetes, dan tumbuhan. Dinding sel perakaran tanaman tersusun atas pektin sehingga diduga Bacillus mampu masuk secara alami dengan mendegradasi pektin melalui produksi enzim. Enzim kitinase dan pektinase dimanfaatkan mikroorganisme sebagai sumber karbon (Tamimi dan Herdyastuti 2013, Salvador et al. 2005).

\section{Antagonisme In Vitro}

Hasil antagonisme in vitro menunjukkan bahwa semua isolat Bacillus mampu menghambat diameter koloni Foc (Gambar 1). Persentase hambatan tertinggi dihasilkan oleh B11 $(93,17 \%)$ sedangkan terendah dihasilkan oleh B18 $(11,80 \%)$. Hal ini menunjukan isolat-isolat Bacillus yang diuji secara in vitro mempunyai berpotensi sebagai penghambat pertumbuhan patogen dalam media biakan. Hasil ini didukung dengan hasil uji filtrat Bacillus terhadap koloni Foc.

\section{Uji Filtrat In Vitro}

Hasil menunjukkan daya hambat yang tinggi isolat Bacillus terhadap Foc terdapat pada isolat-isolat asal Karanganyar dan Mojolaban. Filtrat B3, B7, B9, B11, B12, B18, B24, B26 dan B30 mampu menekan pertumbuhan koloni Foc secara in vitro dengan persentase hambatan berkisar $80-100 \%$ (Gambar 2).

Hasil mengindikasikan semua isolat Bacillus dapat memproduksi senyawa antibiotik yang mampu menekan pertumbuhan koloni Foc. Bacillus dapat menghasilkan antibiotik lebih dari 66 jenis yang bersifat racun terhadap mikroba lain salah satunya yaitu basitrasin yang dapat menghambat 
pembentukan dinding sel patogen (Mochizuki et al. 2005, Soesanto et al. 2008). Hasil uji antagonisme in vitro dan filtrat Bacillus ini didukung dengan uji volatil (uap biakan) agens antagonis.

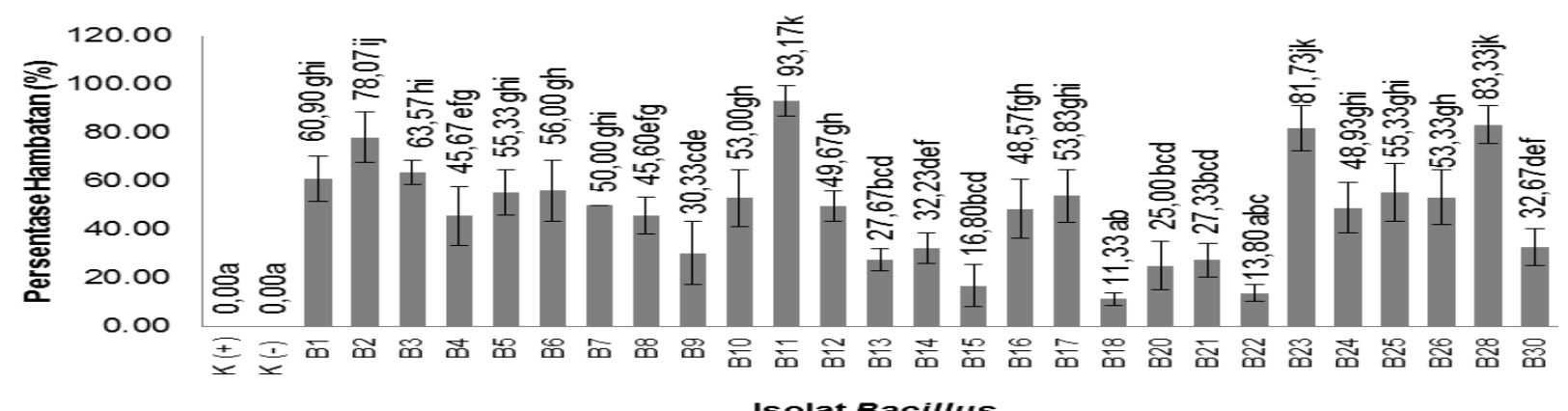

Keterangan: $\quad$ Angka yang diikuti huruf sama tidak berbeda nyata pada uji jarak berganda Duncan $(P<0,05)$, $\mathrm{K}(+)=$ Pembawa Bacillus, $\mathrm{K}(-)$ = Air steril, $\mathrm{Bx}=$ Foc dengan Bacillus $\mathrm{ke}-\mathrm{x}$ ( $\mathrm{x}=$ nomor isolat)

Gambar 1. Histogram pengaruh isolat Bacillus endofit terhadap koloni Foc

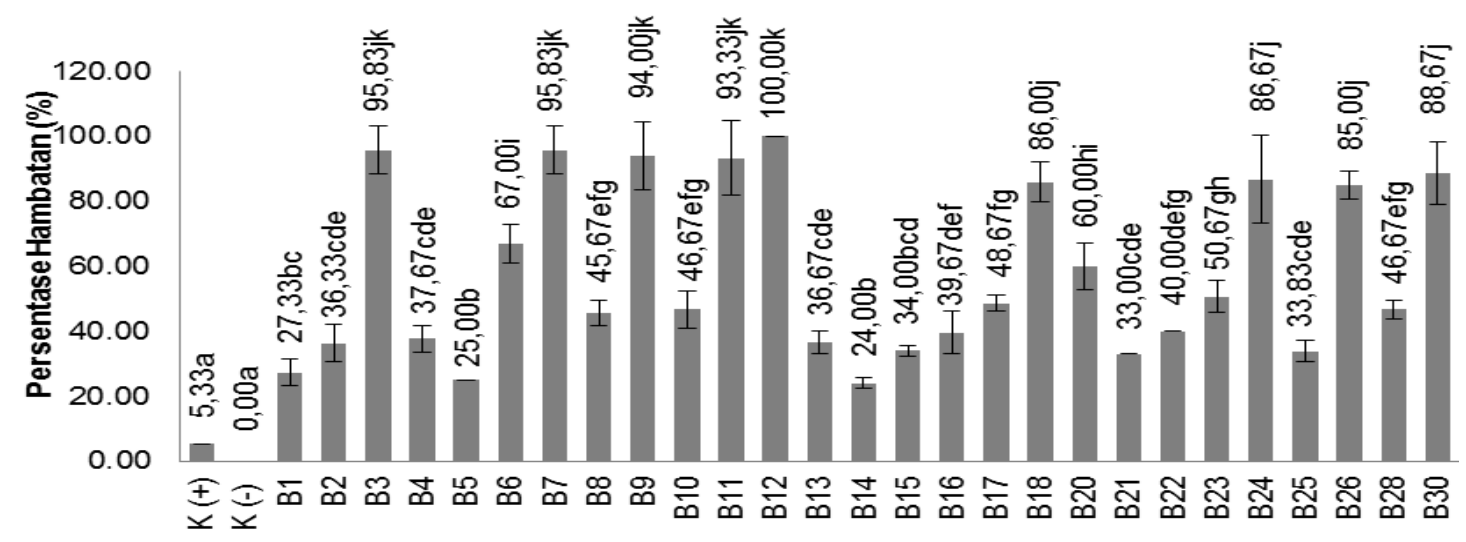

Filtrat Bacillus

Keterangan: Angka yang diikuti huruf sama tidak berbeda nyata pada uji jarak berganda Duncan $(P<0,05)$, $\mathrm{K}(+)=$ Pembawa Bacillus, $\mathrm{K}(-)=$ Air steril, $\mathrm{Bx}=$ Foc dengan Bacillus ke- $\mathrm{x}(\mathrm{x}=$ nomor isolat)

Gambar 2. Histogram pengaruh filtrat Bacillus terhadap pertumbuhan koloni Foc

\section{Uji Volatil In Vitro}

Foc pada media biakan PDA yang ditangkupkan di atas biakan isolat Bacillus pada media biakan NA menunjukkan diameter koloni patogen yang bervariasi. Isolat Foc tanpa agens antagonis mampu tumbuh secara maksimal pada media biakan dengan diameter rata-rata $5,67 \mathrm{~cm}$ pada inkubasi 8 hari, artinya koloni Foc telah tumbuh melingkupi seluruh media biakan.

Berbeda dengan ke-27 isolat uji yang masing-masing perlakuan telah ditangkupkan isolat Bacillus mampu menghentikan pertumbuhan koloni Foc pada inkubasi 4 hari. Hal ini menunjukkan isolat Bacillus mampu menghentikan pertumbuhan Foc ditandai diameter koloni yang bervariasi (Gambar 3).

Isolat B3, B15 dan B16 mampu menekan pertumbuhan Foc secara maksimal dengan diperoleh diameter koloni $1,00 \mathrm{~cm}$. Hal tersebut berarti ada zat penghambat berupa gas yang perannya menahan pembentukan koloni Foc. Sudhanta et al. (2011) menambahkan terhambatnya koloni Foc diduga karena agens antagonis mampu mengeluarkan antibiotik atau alkaloid yang mudah menguap.

\section{Antagonisme In Planta}

Sepuluh isolat Bacillus mampu menekan infeksi Foc in planta, namun tidak semua isolat mampu mengimbas ketahanan bibit pisang di rumah kasa (Tabel 3). Isolat B25 mampu menghambat Foc in planta dengan intensitas penyakit layu terendah sebesar $22,22 \%$ dengan laju infeksi 0,03 unit minggu ${ }^{-1}$ dan nilai LBKPP paling rendah $(525,00)$.

Laju infeksi berkaitan dengan perkembangan penyakit yang sangat dipengaruhi oleh faktor lingkungan. Samson et al. (2004) menambahkan bahwa suhu optimum pertumbuhan Foc berkisar 25$30{ }^{\circ} \mathrm{C}$ dengan suhu minimum $5{ }^{\circ} \mathrm{C}$ dan maksimum mencapai $37^{\circ} \mathrm{C}$. Kondisi lingkungan saat penelitian berpengaruh terhadap keaktifan patogen, kerentanan inang, dan interaksi dalam medium pertumbuhan (Agrios 2005).

Hasil menunjukkan bahwa isolat B6 tidak mampu menghambat Foc. Menurut Susanna (2006) 
ditambahkan oel Sudhanta dan Suprapta (2011) bahwa keefektifan agens antagonis sangat dipengaruhi oleh senyawa metabolit yang mampu menekan infeksi patogen dan kemampuannya dalam mengkolonisasi perakaran. Peningkatan pertumbuhan akar merupakan tanda yang dapat diamati apabila tanaman telah diinokulasikan oleh bakteri endofit (Backman dan Sikora 2008). Bernal et al. (2002) menambahkan agens antagonis dengan jumlah $10^{8}$. $10^{9} \mathrm{spk} \mathrm{\textrm {ml } ^ { - 1 }}$ mampu mengkolonisasi perakaran namun populasi dapat menurun karena kekurangan nutrisi dan kompetisi terhadap organisme lain.

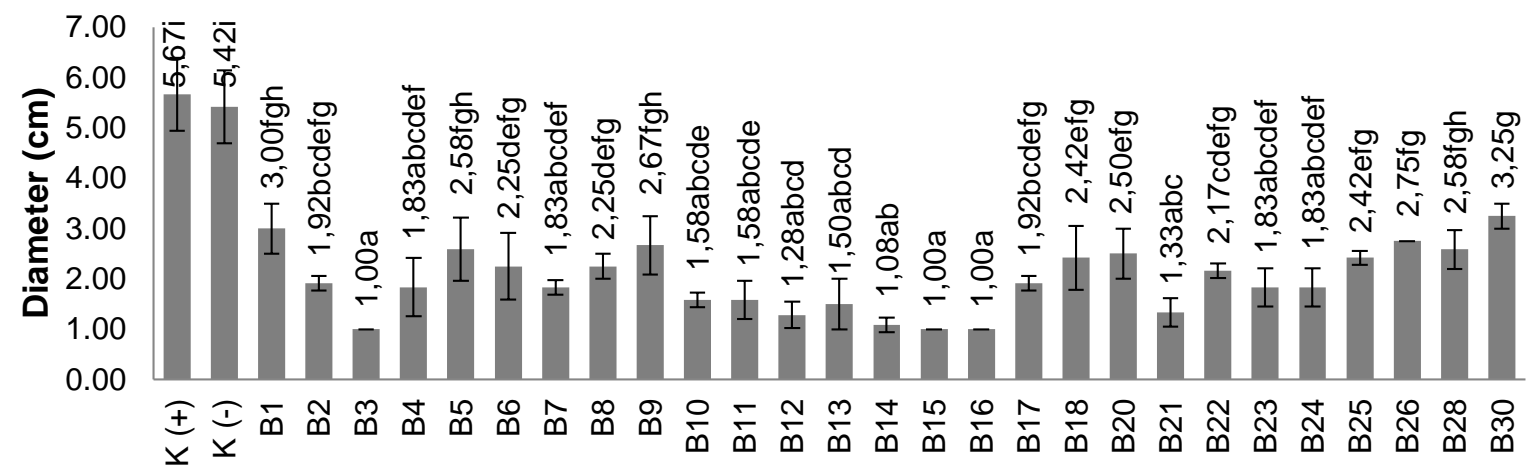

Isolat Bacillus

Keterangan: Angka yang diikuti huruf sama tidak berbeda nyata pada uji jarak berganda Duncan $(P<0,05)$, $\mathrm{K}(+)=$ Pembawa Bacillus, $\mathrm{K}(-)=$ Air steril, $\mathrm{Bx}=$ Foc dengan Bacillus ke- $\mathrm{x}(\mathrm{x}=$ nomor isolat $)$

Gambar 3. Histogram pengaruh uap biakan (volatil) Bacillus terhadap diameter koloni Foc

Tabel 3. Intensitas penyakit, laju infeksi, dan LBKPP perlakuan bibit pisang in planta

\begin{tabular}{llll}
\hline Isolat & Intensitas Penyakit (\%) & Laju Infeksi(unit minggu $\left.{ }^{-1}\right)$ & LBKPP \\
\hline Pembawa Bacillus & $79.63 \pm 3.21 \mathrm{c}$ & 0.20 & $3188.89 \pm 67.36 \mathrm{e}$ \\
Tanpa Bacillus & $77.78 \pm 0.00 \mathrm{C}$ & 0.19 & $3227.78 \pm 172.83 \mathrm{e}$ \\
B1 & $33.33 \pm 5.56 \mathrm{ab}$ & 0.05 & $1088.89 \pm 67.36 \mathrm{bc}$ \\
$\mathrm{B} 2$ & $35.19 \pm 3.21 \mathrm{ab}$ & 0.05 & $1088.89 \pm 89.11 \mathrm{bc}$ \\
$\mathrm{B} 3$ & $38.89 \pm 9.62 \mathrm{~b}$ & 0.06 & $991.67 \pm 172.83 \mathrm{~b}$ \\
$\mathrm{~B} 5$ & $37.04 \pm 8.49 \mathrm{~b}$ & 0.06 & $1380.56 \pm 185.49 \mathrm{C}$ \\
$\mathrm{B} 6$ & $68.52 \pm 3.21 \mathrm{C}$ & 0.14 & $2592.59 \pm 78.58 \mathrm{~d}$ \\
$\mathrm{~B} 11$ & $31.48 \pm 5.24 \mathrm{ab}$ & 0.05 & $1024.07 \pm 191.83 \mathrm{~b}$ \\
$\mathrm{~B} 17$ & $27.78 \pm 9.62 \mathrm{ab}$ & 0.04 & $933.33 \pm 275.67 \mathrm{~b}$ \\
B23 & $31.48 \pm 6.42 \mathrm{ab}$ & 0.05 & $1045.14 \pm 118.81 \mathrm{bc}$ \\
B25 & $22.22 \pm 5.56 \mathrm{a}$ & 0.03 & $525.00 \pm 84.76 \mathrm{a}$ \\
B28 & $40.74 \pm 13.98 \mathrm{~b}$ & 0.07 & $1108.33 \pm 224.24 \mathrm{bc}$ \\
\hline Keterangan: Angka pada kolom sama yang diikuti huruf sama tidak berbeda nyata pada uji jarak berganda
\end{tabular}

\section{KESIMPULAN DAN SARAN}

Infeksi Foc pada pisang dapat ditekan oleh Bacillus melalui mekanisme kompetisi, antibiosis, produksi auksin, kitinase dan pektinase. Aplikasi isolat B25 pada bibit pisang mampu menurunkan intensitas penyakit layu fusarium sebesar $22,22 \%$ dengan

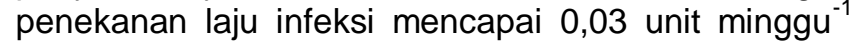
tetapi belum dapat mencegah terjadinya penyakit layu fusarium. Perlu penelitian lanjutan untuk mempelajari sifat fisiologi Bacillus dengan metode yang lain.

\section{DAFTAR PUSTAKA}

Adeline SYT, Sariah M, Jugah K, Son R, Gurmit S. 2008. Endophytic microorganisms as potential growth of banana. J Biocont 53: 541-553.
Agrios GN. 2005. Plant pathology. 5Ed. San Diego (SD): Elsevier Academic Press.

Arrebola E, Jacobs R, Korsten L. 2010. Iturin A is the principal inhibitor in the biocontrol activity of Bacillus amyloliquefaciens PPCB004 against postharvest fungal pathogens. J Appl Microbiol 108: 386-395.

Backman PA, Sikora RA. 2008. Endophytes an emerging tool for biological control. J Biocont 46(1): 1-3.

Bernal G, Illanes A, Ciampi L. 2002. Isolation and partial purification of a metabolite from a mutant strain Bacillus sp. with antibiotic activity against platn pathogenic agents. J Biotech 5(1):1-8. 
Badan Pusat Statistik [BPS]. 2008. Production of fruits in Indonesia. Badan Pusat Statistik. http://www.bps.go.id/. Diakses 10 Januari 2013.

Badan Pusat Statistik [BPS]. 2012. Produksi buahbuahan menurut provinsi tahun 2009-2011. Badan

Lee S, Encarnacion MF, Zentella MC, Flores LG, Escamilla JE, Kennedy C. 2004. Indole-3-acetic acid bisynthesis is deficient in Gluconacetobacter diazotrophicus strains with mutations in cytochrome c biogenesis genes. J Am Soc Microbiol 186(16): 5384-5391.

Leveau JH, Lindow SE. 2004. Utilization of plant hormone indole-3-acetic acid for growth by Pseudomonas putida strain 1290. J Am Soc Microbiol 1(5): 2365-2370.

Mochizuki M, Nishijima T, Toyota K. 2005. Predominant culturable Bacillus species in Japanese arable soils and their potential as biocontrol agents. J Microb Environ 20(1): 61-68.

Nasir N, Jumjunidang, Riska. 2005. Distribusi penyakit layu Fusarium dan layu bakteri Ralstonia pada lokasi sumber bibit dan sekolah lapang pengendalian hama terpadu pisang di Sumatera. $J$ Hort 15(3): 215-222.

Rebib H, Abdeljabbar H, Marc R, Abdellatif B, Ferid L, Najla SN. 2012. Biological control of fusarium foot rot of wheat using fengycin-producing Bacillus subtilis isolated from salty soil. Af J Biotech 11(34): 8464-8475.

Reddy BP, Reddy KRN, Subbarao M, Rao KS. 2008. Efficacy of antimicrobial metabolites of Pseudomonas fluorescens against rice fungal pathogens. Curr Trends Biotechnol Phar 2(1): 178182.

Salvador S, Fontana RC, Silveira MM. 2005. Influence of pectin and glucose on growth and
Pusat Statistik. http://www.bps.go.id/. Diakses 28 Januari 2013.

Hatmanti A. 2002. Introduction to Bacillus spp. J Oseana 25(1): 31-41.

polygalacruronase production by Aspergillus niger in solid-state cultivation. J Microbiol Biotech 32: 371-377.

Samson RA, Hoekstra ES, Frisvad JC. 2004. Introduction to food- and airborne fungi. 7Ed. Utrecht : Centraalbureau voor Schimmelcultures.

Soesanto L, Rokhlani, Prihatiningsih. 2008. Penekanan beberapa mikroorganisme antagonis terhadap penyakit layu gladiol. J Agrivita 30(1): 7583.

Sudhanta IM, Kusnarta IM, Sudana IN. 2011. Uji antagonisme beberapa jenis jamur saprofit terhadap jamur Fusarium oxysporum f.sp.cubense penyebab penyakit layu pada tanaman pisang serta potensinya sebagai agens pengurai seresah. J Agroteksos 21(2): 106-119.

Susanna. 2006. Pemanfaatan bakteri antagonis sebagai agen biokontrol penyakit layu (Fusarium oxysporum f.sp. cubense) pada tanaman pisang. J Floratek 2: 114-121.

Sutariati GAK, Widodo, Sudarsono, llyas S. 2006. Karakter fisiologis dan keefektifan isolat rizobakteri sebagai agens antagonis Colletotrichum capsici dan rizobakteri pemacu pertumbuhan tanaman cabai. J Kultura 4(1): 28-34.

Tamimi M, Herdyastuti N. 2013. Analysis functional groups using ft-ir spectroscopy of chitin variation as Pseudomonas sp. tnh-54 substrates. J Chem 2(2): 47-51. 